\title{
MANAJEMEN STRES PADA GURU YANG MENGAJAR ANAK BERKEBUTUHAN KHUSUS DI MASA PANDEMI COVID-19
}

\author{
Pamela Hendra Heng ${ }^{1}$, Jessica Chandhika ${ }^{2}$, Nurhayati Silalahi ${ }^{3}$ \\ ${ }^{1}$ Fakultas Psikologi, Universitas Tarumanagara \\ Surel: pamelah@fpsi.untar.ac.id \\ ${ }^{2}$ Fakultas Psikologi, Universitas Tarumanagara \\ Surel: jessica@fpsi.untar.ac.id \\ ${ }^{3}$ Fakultas Psikologi, Universitas Tarumanagara \\ Surel: nurhayati.705180014@stu.untar.ac.id
}

\begin{abstract}
The COVID-19 pandemic has brought many changes to the world of education, including among teachers of Children with Special Needs (ABK). In addition to the fear of the spread of COVID-19 which is increasing every day, ABK teachers are faced with conditions that force them to make difficult adjustments. Most teachers with special needs complain that there are many challenges, namely the lack of training and application of online learning, especially during teaching where the teacher communicates with hand and mouth movements, often the movements are late in the video so that the special needs children often misunderstand which can lead to difficulties in teaching. In addition, the daily activities of teachers also face a big challenge in doing work from home with limited or inadequate facilities and distractions of family members who are around them. This creates potential stress for ABK teachers. For this reason, stress management and time management are an effort of the Tarumanagara University Community Service (PKM) team given to ABK teachers. The targets of this PKM are ABK teachers from five special schools (SLB), namely SLB A in Yogyakarta, SLB B in Ambon, SLB C in Batu Bara, $S L B D$ in Batam, and SLB E in East Kalimantan. During the implementation of psychoeducation, the pre-test and post-test methods were given to 24 ABK teachers. The measuring instrument used in the test is The Perceived Stress Scale (PSS), 10 items made by Sheldon Cohen (1983) and the time management measurement tool is the Time Management Questionnaire (TMQ), 11 items made by Britton and Tesser (1991). The results show that the stress level of ABK teachers is at a low level, while time management is at a high level. Furthermore, there was an increase in the stress level of $A B K$ teachers and there was a decrease in the level of time management of ABK teachers during the pre-test and post-test.
\end{abstract}

Keywords:COVID-19 pandemic, stress management, time management

\begin{abstract}
ABSTRAK
Pandemi COVID-19 membawa banyak perubahan terhadap dunia pendidikan, termasuk di kalangan guru Anak Berkebutuhan Khusus (ABK). Di samping ketakutan akan penularan COVID-19 yang meningkat setiap hari, para guru ABK dihadapkan dengan kondisi yang memaksa mereka untuk melakukan penyesuaian yang tidak mudah. Kebanyakan guru ABK mengeluh banyak tantangan yakni kurang pelatihan dan penerapan pembelajaran online, khusus pada saat pengajaran berlangsung dimana guru berkomunikasi dengan gerakan tangan dan mulut, sering gerakannya terlambat dalam video sehingga ABK sering salah mengerti yang dapat mengakibatkan kesulitan dalam mengajar. Selain itu aktivitas para guru sehari-hari juga mendapat tantangan yang besar melakukan work from home dengan fasilitas yang terbatas atau kurang memadai, dan distraksi anggota keluarga yang berada di sekitarnya. Hal ini menimbulkan potensi stres terhadap guru ABK. Untuk itu, manajemen stres dan manajemen waktu menjadi sebuah upaya tim Pengabdian Kepada Masyarakat (PKM) Universitas Tarumanagara yang diberikan kepada para guru ABK. Target sasaran PKM ini adalah guru ABK yang berasal dari lima Sekolah Luar Biasa (SLB) yaitu SLB A di Yogyakarta, SLB B di Ambon, SLB C di Batu Bara, SLB D di Batam, dan SLB E di Kalimantan Timur. Saat pelaksanaan psikoedukasi, metode pre-test dan post-test diberikan kepada 24 guru ABK. Alat ukur yang dipakai pada test tersebut adalah The Perceived Stress Scale (PSS), 10 butir yang dibuat oleh Sheldon Cohen (1983) dan alat ukur manajemen waktu adalah Time Management Questionnaire (TMQ), 11 butir yang dibuat Britton dan Tesser (1991). Hasil menunjukan stres yang dimiliki guru ABK berada pada tingkat rendah, sementara manajemen waktu berada pada tingkat yang tinggi. Selanjutnya, terdapat peningkatan pada tingkat stres guru ABK dan terdapat penurunan pada tingkat manajemen waktu guru ABK selama pre tes dan pos tes.
\end{abstract}

Kata Kunci: pandemi COVID-19, manajemen stres, manajemen waktu. 


\section{PENDAHULUAN}

Severe Acute Respiratory Syndrome Coronavirus-2 (SARS-CoV-2) adalah sejenis virus yang sering disebut dengan COVID-19 (Yuki, Fujiogi, \& Koutsogiannaki, 2020) dan menyebar pertama sekali di Wuhan, sebuah kota di negara Cina pada bulan Desember 2019 (Yang, Bin, \& $\mathrm{He}, 2020$ ). Penyebarannya sangat cepat ke berbagai negara hingga jumlah kasus di dunia per 31 Mei 2021 telah mencapai 171.006.182 (WHO, 2021) dan 1.803.361 diantaranya adalah kasus di Indonesia (Kemenkes RI, 2021). Atas pandemi COVID-19 ini, perubahan-perubahan besar di berbagai aspek kehidupan manusia terjadi. Pada aspek kesehatan, pemerintah di berbagai negara memberlakukan social distancing untuk mencegah penularan COVID-19 dari satu orang ke orang lain. Namun penerapan social distancing ini mengganggu rutinitas kehidupan sehari-hari manusia karena berdampak besar terhadap pendidikan dan bidang lain kehidupan manusia. Tidak sedikit sekolah ditutup sebagaimana laporan dari United Nations Educational, Scientific and Cultural Organization (UNESCO dalam Lee, 2020) dimana lebih dari 90\% (1,5 miliar) siswa tidak dapat melanjutkan pendidikannya akibat penutupan sekolah.

Ternyata dampak COVID-19 terhadap aspek pendidikan tidak hanya dirasakan oleh siswa akan tetapi juga para guru. Sebuah penelitian oleh Donitsa-Schmidt dan Ramot (2020) mengatakan sejumlah guru di Israel harus membuat keputusan cepat mengenai kurikulum dan silabus yang harus disesuaikan dengan keadaan pandemi COVID-19. Mereka harus membuat sistem pembelajaran jarak jauh dan tidak mengetahui kepastian sampai berapa lama pembelajaran jarak jauh ini berlangsung. Mereka dihadapkan pada alat teknologi yang memungkinkan mereka keluar dari zona nyaman regular mereka selama ini dan melibatkan siswa secara interaktif dan kolaboratif. Mereka harus berusaha meningkatkan keterampilan mengajar online, mencari bantuan pengembangan profesional untuk meningkatkan kecakapan teknis pedagogik, dan berupaya untuk menggunakan beragam alat pembelajaran. Oleh karena itu, mereka dipaksa oleh keadaan untuk membiasakan diri dengan manajemen pembelajaran dan platform digital yang disediakan oleh lembaga pendidikan. Sesungguhnya para guru ini sangat beruntung karena selain alat digital yang ditawarkan oleh lembaga, mereka juga menerima pelatihan bahkan tutorial pribadi untuk membantu mereka mempelajari alat terlebih dahulu. Hanya selama tiga minggu pertama mereka mengalami kendala, cemas, panik, dan penuh gejolak dalam beradaptasi dengan sistem pengajaran baru. Setelah itu mereka sudah merasa terbiasa, nyaman, dan kompeten dalam menggunakannya. Tidak semua guru seberuntung guru di Israel dalam menghadapi perubahan karena pandemi COVID-19 ini.

Di negara India, sekelompok guru merasa tidak puas dan kecewa atas sikap pemerintah yang hanya meliburkan para siswa, sementara guru harus kembali bekerja seperti biasanya yaitu hadir ke sekolah. Hal ini menciptakan dampak psikologis pada moral para guru sebab dari antara mereka terdapat beberapa guru senior yang sudah dikategorikan usia tua yang masuk pada kelompok rentan tertular COVID-19. Mereka dihantui oleh rasa cemas dan takut apabila kembali ke keluarga dan masyarakat. Itulah sebabnya para guru tersebut menyerukan kepada pemerintah India agar memikirkan cara bagaimana menyeimbangkan antara menjaga para guru tetap terlibat dalam bidang akademis tanpa membahayakan kehidupannya (Bhat et. al., 2020).

Terkait dengan kecemasan di masa pandemi COVID-19, sekelompok guru di negara Filipina juga mengalaminya. Berdasarkan penelitian yang dilakukan oleh Talidong dan Toquero (2020) mengatakan bahwa kecemasan muncul disebabkan para guru tidak dapat melakukan hal-hal yang dulu mereka bisa lakukan karena sekarang gaya hidup mereka berubah selama pandemi COVID19. Para guru juga merasa cemas terhadap keselamatannya dan orang yang mereka cintai seperti anak, ibu, ayah, dan keluarga. Kecemasan ini mempengaruhi gaya hidup mereka. Untuk mengatasi rasa cemas tersebut, mereka mencoba memiliki pandangan positif dalam hidup di tengah pandemi COVID-19. Mereka melakukan beberapa hal seperti selalu membawa alkohol disinfektan ketika mereka keluar rumah, membaca buku, menonton televisi, memasak, bermain 
game mobile, tidur, dan berolahraga.

Berdasarkan hasil penelitian yang dilakukan oleh Smith (2020) ada 38\% dari 35 guru ABK yang berasal dari kelompok Eropah Amerika, Afrika Amerika, dan Amerika Latin melaporkan dirinya frustrasi dan putus asa dengan kurangnya keterlibatan siswa maupun orang tua. Hal ini juga dipicu dengan para guru mengalami kesulitan dan tidak memiliki kemampuan yang memadai dalam memberikan layanan pendidikan khusus kepada anak didiknya dengan berkebutuhan khusus terutama bagi anak didik yang memiliki banyak disabilitas atau lebih signifikan. Demikian juga dengan penelitian yang dilakukan oleh Hamilton et al. (2020) dimana guru kekurangan pelatihan tehnologi dan sumber daya menghadapi banyak hambatan ketika mengajar siswa berkebutuhan khusus secara online.

Para guru di Indonesia pun tidak terlepas dari dampak dan perubahan yang diakibatkan oleh pandemi COVID-19. Dalam penelitian Rokhani (2020) menjelaskan bahwa guru Sekolah Dasar (SD) Dengkek 01 akhirnya membawa semua pekerjaannya dan dilakukan dari rumah. Beberapa dampak positif seperti merasa aman bekerja karena terhindar dari COVID-19, mengurangi biaya transportasi dari rumah ke sekolah, mereka juga mengalami dampak negatif, yaitu muncul rasa jenuh karena suasana yang monoton, kurang interaksi dengan guru yang lain dan juga peserta didik. Sebagian orang menyatakan kualitas proses pembelajaran online menurun, dan tidak fokus bagi peserta didik maupun guru saat kegiatan belajar mengajar, sebab adanya gangguan jaringan sistem dalam jaringan (daring) dan gangguan interaksi dengan anggota keluarga yang berada di sekitar mereka.

Berdasarkan CNN Indonesia (2020), seorang guru anak berkebutuhan khusus menjelaskan bahwa sangat sulit untuk mengajar jarak jauh selama masa pandemi COVID-19. Dirinya yang secara khusus menanganin murid yang mengalami sensory processing disorder yaitu kondisi yang mengakibatkan sulit merespons informasi yang masuk melalui pancaindra karena adanya hambatan pada otak. Berulang kali siswanya menolak untuk belajar di rumah, karena merasa tidak terbiasa dan berpikir bahwa belajar harus di sekolah. Perlu beberapa hari untuk membuat siswanya paham dengan kondisi yang ada. Belum lagi, kondisi kedua orang tua siswanya yang masih datang ke kantor untuk bekerja tidak dapat mendampingi setiap hari. Hal ini tentu membuat sang guru menjadi sangat cemas dan stress dengan kondisi yang dialaminya.

Berdasarkan informasi di atas, guru ABK memiliki potensi mengalami stres selama masa pandemi COVID-19.

\section{Permasalahan Mitra}

Permasalahan mitra yakni SLB A Yogyakarta, SLB B Ambon, SLB C Batu Bara, SLB D Batam, dan SLB E Kalimantan Timur secara umum dapat dirumuskan sebagai berikut: (1) Terdapat guru yang mengeluh tentang kesulitan kegiatan mengajar belajar dengan anak berkebutuhan khusus mengalami selama masa pandemi COVID-19; (2) Terdapat permasalahan meningkatnya tuntutan yang dapat melampaui kemampuan guru ABK selama masa pandemi COVID-19. Selain online, mereka juga harus home visit ke rumah siswanya yang autis. Jadi baik online dan luar jaringan (luring) digunakan oleh guru ABK. Ini membuat waktu mereka banyak tersita. Ada sebagian siswa ABK yang mengharuskan tetap tatap muka. Contohnya siswa ABK dengan hambatan autis. Mereka tidak bisa mengikuti pembelajaran online. Ini keluhan ibu guru dari SLB Ambon (3) Terdapat kesulitan memenuhi kebutuhan persiapan mengajar dan kebutuhan keluarga karena keterbatasan waktu.

\section{Solusi Mitra}

Dari kajian analisis di atas kebutuhan dari SLB A Yogyakarta, SLB B Ambon, SLB C Batu Bara, SLB D Batam, dan SLB E Kalimantan Timur, maka langkah-langkah penyelesaiannya sebagai berikut: (1) Pemberian psikoedukasi mengenai pemahaman dari stres pada guru $\mathrm{ABK}$ di 
masa pandemi COVID-19 melalui manajemen stres dan manajemen waktu (2) Psikoedukasi ini dapat meningkatkan pengetahuan dan kemampuan guru $\mathrm{ABK}$ dalam menghadapi stres di masa pandemi COVID-19 (3) Berdasarkan ketidakmampuan membagi waktu untuk tugas mengajar dan keluarga, maka tim PKM UNTAR memberi solusi melalui psikoedukasi manajemen waktu.

\section{METODE PELAKSANAAN PKM}

Metode pelaksanaan yang diusulkan adalah penyuluhan berupa psikoedukasi pada guru bahkan kepada kepala sekolah anak berkebutuhan khusus agar tercapainya maksud dan tujuan dari pengabdian kepada masyarakat ini. Pelaksanaan diawali dengan menghubungi kepala sekolah SLB B Ambon dan kepala sekolah SLB C Batubara untuk mengurus perizinan, mengurus persiapan kegiatan, pelaksanaan kegiatan sesuai dengan waktu yang telah ditentukan. Alat ukur yang digunakan adalah berupa kuesioner, yang terdiri dari 2 alat ukur. Alat ukur pertama adalah The Perceived Stress Scale (PSS), yang terdiri dari 10 butir (Cohen, 1983) dengan menggunakan skala Likert $0-4$, dari tidak pernah sampai sangat sering. Alat ukur ini unidemensional. Alat ukur yang kedua adalah The Time Management Questionnaire (TMQ) terdiri dari 11 butir dengan menggunakan skala Likert 1-4 dari sangat tidak setuju sampai sangat setuju. Alat ukur ini terdiri dari empat dimensi yaitu dimensi menentukan tujuan dengan nilai Alpha Cronbach sebesar 0.610, dimensi menyusun prioritas dengan nilai Alpha Cronbach sebesar 0.869, dimensi membuat jadwal dengan nilai Alpha Cronbach sebesar 0.937, dan dimensi meminimalisasi gangguan dengan nilai Alpha Cronbach sebesar 0.620. Total keseluruhan subyek berjumlah 24 orang guru $\mathrm{ABK}$ dengan usia di atas 20 tahun, terdiri dari 2 laki-laki dan 22 perempuan, berasal dari lima SLB yaitu SLB A di Yogyakarta, SLB B di Ambon, SLB C di Batu Bara, SLB D di Batam, dan SLB E di Kalimantan Timur.

Selama masa pandemi COVID-19, maka seminar maupun pengumpulan data dilakukan secara online. Penyebarkan kuesioner yang berisi perkenalan diri peneliti, informed consent, alat ukur PSS dan alat ukur TMQ secara online melalui google form yang disebarkan melalui Whatsapp group partisipan yang telah dikoordinasikan dengan ke lima koordinator sebelum dan sesudah psikoedukasi diberikan.

Sebelum penyuluhan dilakukan, para peserta diberikan kuesioner pre-test untuk mengetahui pengetahuan mengenai persepsi stres manajemen waktu dan di masa pandemi COVID-19. Setelah penyuluhan peserta diberikan kuesioner post-test untuk mengetahui pengetahuan mengenai stres dan manajemen waktu di masa pandemi COVID-19 serta penanganannya. Akhir dari kegiatan ini ialah menghitung hasil selisih dari pre-test dan post-test untuk menilai efektifitas dari penyuluhan yang diberikan. Selanjutnya, laporan kegiatan dibuat dan jurnal ilmiah disiapkan untuk dapat dipublikasikan.

\section{HASIL DAN PEMBAHASAN}

Kegiatan Pengabdian Kepada Masyarakat dalam bentuk Penyuluhan Psikoedukasi atau Seminar yang dilakukan secara daring dilaksanakan pada hari Selasa, 4 Mei 2021 melalui seminar daring dengan platform Zoom Meeting. Kegiatan disusun oleh panitia dengan susunan acara sebagai berikut:

13.00-13.15: registrasi peserta

13.15-13.25: pembukaan oleh MC

13.25-13.35: sambutan dari ketua tim PKM

13.35-14.00: pemaparan materi Stress

14.00-14.30: pemaparan materi Manajemen Stres

14.30-15.00: Tanya-jawab dan diskusi

15.00: Penutupan 


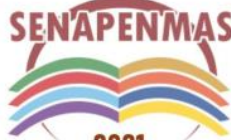

2021
Seminar Nasional Hasil Penelitian dan Pengabdian Kepada Masyarakat 2021

Pengembangan Ekonomi Bangsa Melalui Inovasi Digital Hasil Penelitian dan Pengabdian Kepada Masyarakat Jakarta, 21 Oktober 2021

Target peserta pada awal diharapkan 30 orang tetapi peserta yang hadir dalam psikoedukasi online sebanyak 42 guru dan kepala sekolah anak berkebutuhan khusus dari SLB A di Yogyakarta, SLB B di Ambon, SLB C di Batu Bara, SLB D di Batam, dan SLB E di Kalimantan Timur. Partisipan terdiri dari dua kategori yakni yang berusia: 20 - 40 tahun (54.2\%), dan berusia $>40$ tahun $(45.8 \%)$. Jenis kelamin partisipan adalah laki-laki sejumlah $8.3 \%$ dan perempuan 91.7\%. Jadi jenis kelamin partisipan terbanyak adalah perempuan. Ditinjau dari asal SLB, 8.3\% dari SLB A Yogyakarta, 41.7 dari SLB B Ambon, 16.7\% dari SLB C Batu Bara, 29.2\% dari SLB D Batam, dan 4.2\% dari SLB Kalimantan Timur. Partisipan dalam penelitian ini sejumlah 42 orang namun yang dapat diolah datanya hanya sejumlah 24 orang. Hypothetical Mean Variable Stres sebesar 2.5. Hasil Empirical Mean dimana Hypothetical Mean diketahui sebesar 2.5 dan Empirical Mean sebesar 1.2708 pada pre-test dan 1,4306 pada post-test, sehingga berarti gambaran stres guru ABK rendah. Namun jika dilihat pada hasil Hypothetical Mean dan Empirical Mean Manajemen Waktu, dimana Hypothetical Mean sebesar 3 dan Empirical Mean 4.1788 pada pre-test dan 3.9809 pada post-test, sehingga ini menunjukkan gambaran manajemen waktu guru ABK tinggi.

Analisa hasil atas pemberian penyuluhan berupa psikoedukasi ini didapatkan dari selisih antara nilai pre-test dengan nilai post-test yang diberikan kepada peserta.

Terdapat 1 buah pertanyaan mengenai pengetahuan peserta mengenai Stres dan 2 pertanyaan manajemen waktu. Dari hasil jawaban peserta seminar daring dilakukan penghitungan rerata dari setiap variable yang dijelaskan baik dari hasil pre-test maupun hasil post-test. Berikut ini akan dijelaskan mengenai perbandingan nilai pre-test dan post-test setiap variabelnya seperti pada table 1.

Tabel 1. Hasil Perbandingan rerata nilai Pre-test dan Post-test Psikoedukasi

\begin{tabular}{lcc}
\hline \multicolumn{1}{c}{ Variabel } & Pre-test & Post-test \\
\hline $\begin{array}{l}\text { Perceive Stress } \\
\text { Scale }\end{array}$ & 1.2708 & 1.4306 \\
\hline Time & 4.1788 & 3.9809 \\
Management & & \\
Questionnaires & & \\
\hline
\end{tabular}

Dari hasil perbandingan atas nilai pre-test dengan post-test untuk variable Stres diketahui terdapat selisih 0.1598 poin. Dengan adanya selisih ini menunjukan bahwa terdapat perubahan yakni adanya peningkatan pemahaman dari peserta mengenai Stres guru ABK kepada anak berkebutuhan khusus di masa pandemi COVID-19 ini. Stres dalam penyuluhan disampaikan dengan menjelaskan pengertian dari Stres, bentuk atau reaksi dari stres, faktor yang memengaruhi stres, dan materi mengenai Manajemen stres.

Untuk variable Time Management pada guru Anak berkebutuhan khusus diketahui juga terdapat selisih hasil pre-test dengan hasil post-test. Diketahui adanya selisih sebesar 0.1979 poin dari post-tes dengan pre-test, yang menunjukan adanya penurunan pemahaman peserta mengenai manajemen waktu pada guru anak berkebutuhan khusus di masa pandemi COVID-19. Materi Manajemen Waktu anak berkebutuhan khusus di masa pandemi COVID-19 dijelaskan kepada peserta penyuluhan mencakup pengertian dari Manajemen Waktu yang kreatif, hambatan utama mengatur waktu, dan bagaimana cara mengatasi.

Menurut Mc Shane (dalam Septiwan, 2018) bahwa dalam menghadapi stres, seseorang sangat bergantung pada persepsi individu sendiri dan penyebab stres yang sama bisa jadi mengakibatkan dampak yang berbeda pada tiap individu. Walaupun secara statistik tidak terlalu besar signifikansinya, namun dari komentar kesan peserta bahwa pembahasan seminar itu mudah 
diaplikasikan dan mereka merencanakan segera melakukan pada kehidupan mereka. Hasil penelitian Rochani (2019) mengatakan bahwa pelatihan manajemen stres mampu mereduksi tingkat stres guru selama masa adaptasi kebiasaan baru. Dengan demikian sejalan dengan komentar dari para guru ABK, maka psikoedukasi yang dilaksanakan oleh tim pengabdian kepada masyarakat dari UNTAR dapat dinyatakan berhasil memberikan wawasan dan pemenuhan kebutuhan peserta serta manfaat bagi para guru yang mengajar ABK di masa pandemi COVID-19.

\section{KESIMPULAN DAN SARAN}

Berdasarkan hasil analisa data yang dilakukan mengenai manajemen stres dan manajemen waktu guru ABK, maka dapat diambil kesimpulan bahwa stres guru ABK rendah dan manajemen waktu yang dimiliki guru ABK tinggi. Perbedaan pre-test dan post-test ditemukan pada hasil stres guru ABK maupun pada manajemen waktu guru ABK. Selanjutnya, hasil uji beda pre-test dan post-test berdasarkan demografi baik usia, jenis kelamin, dan asal SLB ditemukan bahwa tidak adanya perbedaan stres guru ABK. Demikian juga pada hasil uji beda manajemen waktu guru $\mathrm{ABK}$ bahwa tidak ditemukan perbedaan baik berdasarkan demografi maupun dimensi.

Manfaat yang diperoleh oleh para guru ABK sebagai peserta seminar adalah memiliki pengetahuan dan kemampuan dalam menghadapi stres di masa pandemi COVID-19. Para peserta mengungkapkan bahwa mereka mendapat banyak manfaat. Melalui psikoedukasi, mereka memiliki pemahaman yang baik dan benar tentang manajemen stres dan waktu serta termotivasi untuk segera menerapkannya. Mereka merasa bahagia dan bersyukur sebagai peserta karena topik dan materi psikoedukasi yang mereka terima sangat bermanfaat. Itulah sebabnya, mereka mengharapkan kegiatan psikoedukasi tetap dilaksanakan dengan topik-topik yang variatif dan dapat membantu para guru ABK dalam tugas-tugasnya sebagai pengajar.

Manfaat PKM telah memberikan pengayaan di bidang psikologi pendidikan tentang guru ABK tentang kondisi stres dan pemakaian waktu mereka. Selanjutnya, saran yang dapat diberikan kepada guru ABK agar mereka mempraktekan apa yang sudah mereka dapat dari psikoedukasi manajemen stres dan manajemen waktu dalam pekerjaan dan kehidupan mereka yang diharapkan akan berdampak positif untuk diri mereka, keluarga dan peserta didik. Selain itu, kepala sekolah dan pemerintah perlu memberikan dukungan dari sisi lain antara lain sarana prasarana yang memadai untuk kegiatan belajar mengajar guru ABK dengan peserta didiknya, hal yang berkaitan dengan kurikulum dan pelatihan untuk para guru ABK sehingga diharapkan kegiatan belajar mengajar dapat dioptimalkan dalam masa pandemi COVID-19.

Dari segi materi yang telah direncanakan cukup baik karena kedua materi tersampaikan dengan baik dan sesuai dengan waktu yang ditentukan. Kemampuan peserta dalam penguasaan materi seminar adalah sangat baik terbukti dengan beberapa pertanyaan, masukan, dan kesan para peserta. Maka secara keseluruhan kegiatan psikoedukasi dapat dikatakan berhasil karena tim PKM dari UNTAR dapat memberikan pemenuhan kebutuhan peserta guru yang mengajar ABK di masa pandemi COVID-19.

\section{Ucapan Terima kasih}

Peneliti mengucapkan terima kasih kepada semua SLB yang telah menjadi mitra kami, dan para guru ABK yang terlibat dalam kegiatan psikoedukasi Manajemen Stres dan Manajemen Waktu. Lembaga Penelitian dan Pengabdian kepada Masyarakat, Universitas Tarumanagara, atas dukungan yang telah diberikan.

\section{REFERENSI}

Andriany, A. R., Pratiwi, A. M. A., \& Pertiwi, M. (2021). Hubungan anatara subjective wellbeing dengan burnout pada guru anak berkebutuhan khusus selama pandemi COVID-19. 
Seminar Nasional Hasil Penelitian dan Pengabdian Kepada Masyarakat 2021 Pengembangan Ekonomi Bangsa Melalui Inovasi Digital Hasil Penelitian dan Pengabdian Kepada Masyarakat Jakarta, 21 Oktober 2021

Syntax, 3(4).

Aufar, A. F. (2020). Kegiatan relaksasi sebagai coping stress di masa pandemi COVID-19. Kolaborasi Resolusi Konflik, 2(2), 157-163.

Bhat, R., Singh, V. K., Naik, N., Kamath, C. R., Mulimani, P., \& Kulkarni, N. (2020). COVID 2019 outbreak: The disappointment in Indian teachers. Asian Journal of Psychiatry, 50, 102047. doi: 10.1016/j.ajp.2020.102047

Britton, B.K. \& Tesser, A. (1991) Effects of time-management practices on college grades. Journal of Educational Psychology, 83, 3, 405-410.

Cohen, S., Kamarck, T., \& Mermelstein, R. (1983). A global measure of perceived stress. Journal of Health and Social Behavior, 24, 385-396.

CNN Indonesia. (2020). Corona dan dilema guru mengajar siswa berkebutuhan khusus. CNN Indonesia. https://www.cnnindonesia.com/nasional/20200421163541-20-495770/coronadan-dilema-guru-mengajar-siswa-berkebutuhan-khusus

Donitsa-Schmidt, S., \& Ramot, R. (2020). Opportunities and challenges: teacher education in Israel in the Covid-19 pandemic. Journal of Education for Teaching, 1-10. doi:10.1080/02607476.2020.1799708

Hamilton, L. S.,m Kaufman, J. H., \& Diliberti, M. (2020). Teaching and leading through a pandemic: Key findings from the American Educator Panel Spring 2020 COVID-19 Surveys.

Hatmanti, N. M., \& Septianingrum, Y. (2019). Faktor-faktor yang mempengaruhi stres akademik mahasiswa keperawatan.: Factors that Influence the Academic Stress of nursing students. Jurnal Ilmiah Keperawatan (Scientific Journal of Nursing), 5(1), 40- 46. https://doi.org/10.33023/jikep.v5i1.217

Heng, P.H., Syahrini, R., \& Silalahi, N. (2021). Description of quality of life of teachres for special needs students during the pandemic of COVID-19. Waiting for publication by Atlantis Press Publicher

Kementerian Kesehatan Republik Indonesia. (2021, Februri 2). Situasi covid 19. https://www.kemkes.go.id/

Lee, J. (2020). Mental effects of school closures during covid 19. Journal of Child \& Adolescent, 4, 421.DOI: https://doi.org/10.1016/S2352-4642(20)30109-7

Lumban Gaol, N. T. (2021). Faktor-faktor penyebab guru mengalami stres di sekolah. Jurnal Educational Guidance and Counseling Development, 17(28), 2615-8358.

Marpaung, J. (2016) Counseling approach behavior rational emotive therapy in reducing stress. Jurnal Kopasta, 3, 23-31.

Murphy, S. L., \& McCaarthy, C. J. (2016) Stress prevention and mindfulness: A psychoeducational_and support group for $\quad$ teachers. https://doi.org/10.1080/01933922.2016.1151470

Rochani. (2020). Pelatihan manajemen stress untuk meredukasi tingkat stress guru selama masa adaptasi kebiasaan baru. Jurnal Horizon Pedagogia, 1(2), 11-21

Rokhani, C, T, S. (2020). Pengaruh work from home (WFH) terhadap kinerja guru SD negeri Dengkek 01 Pati selama masa pandemi covid. Jurnal of Education, Psychology and Counseling, 2(1), 2716-4446. https://ummaspul.ejournal.id/Edupsycouns/article/view/500/292

Septiawan, B. (2018) Analisa faktor penyebab dan manajemen stres pada kepala sekolah Bahrul Maghfiroh Malang. Jurna al-Hikmah, 6(1), 36-45.

Smith, C. (2020). Challenges and opportunities for teaching students with disabilities during the COVID-19 pandemic. International Journal of Multidisciplinary Perspectives in Higher Education, 5(1), 167-173.

Talidong, K. J. B., \& Toquero, C. M. D. (2020). Philippine teachers' practices to deal with 


$$
\text { anxiety amid COVID-19. Journal of Loss and Trauma, 1-7. }
$$
doi:10.1080/15325024.2020.1759225

WHO. (2020, February 2). WHO Coronavirus Disease (COVID-19) Dashboard. https://covid19.who.int/

Yang, H., Bin, P., \& He, A. J. (2020). Opinions from the epicenter: an online survey of university students in Wuhan amidst the COVID-19 outbreak1. Journal of Chinese Governance, $\quad 1-\quad$ 15. doi:10.1080/23812346.2020.1745411

Yuki, K., Fujiogi, M., \& Koutsogiannaki, S. (2020). COVID-19 pathophysiologi: A review. Clinical Immunology, 215, 1521-6616. https://doi.org/10.1016/j.clim.2020.108427 